\title{
Effect of Nitrogen Levels and Scheduling on Yield and Economics of Aerobic Rice (Oryza sativa L.) in vertisols of Chhattisgarh Plains
}

\author{
H. L. Sonboir*, N. Pandey, Bhujendra Kumar and B. K. Sahu \\ Department of Agronomy, College of Agriculture, Indira Gandhi Krishi \\ Vishwavidyalaya, Raipur, Chhattisgarh-492012, India \\ *Corresponding author
}

\section{Keywords \\ Nitrogen, \\ scheduling, levels, aerobic rice, yield, economics, nitrogen uptake}

\section{Article Info}

\section{Accepted:}

25 February 2020

Available Online:

10 March 2020

\section{A B S T R A C T}

An experiment was conducted during three consecutive kharif season of 2012, 2013 and 2014 at Raipur in clay soil having neutral reaction, low nitrogen, medium phosphorus and high potassium content to find out effect of levels and scheduling of nitrogen on yield and economics of aerobic rice. The experiment was laid out in split plot design with three replications. Two levels of nitrogen in main plot viz.,120 kg N/ha and $150 \mathrm{~kg} \mathrm{~N} / \mathrm{ha}$ and six nitrogen schedules in sub plot viz., S1-2 splits (1/2 at basal+ 1/2 at panicle initiation), S2- 2 splits ( $1 / 2$ at 10 days after emergence+ $1 / 2$ at panicle initiation), S3- 3 splits (1/3 at basal+ $1 / 3$ at active tillering $+1 / 3$ at panicle initiation), S4- 3 splits (1/3 at 10 days after emergence $+1 / 3$ at active tillering $+1 / 3$ at panicle initiation), S5- 4 splits ( $1 / 4$ basal $+1 / 4$ at active tillering+ $1 / 4$ at panicle initiation+ $1 / 4$ at flowering) and S6-4 splits (1/4 at 10 days after emergence $+1 / 4$ at active tillering $+1 / 4$ at panicle initiation $+1 / 4$ at flowering) was assigned. The test variety was IGKV R1 coarse seed maturing in 125 days and semi dwarf in nature. Application of different levels of nitrogen did not exhibit any significant effect on grain yield, straw yield, net return and B: $\mathrm{C}$ ratio of aerobic rice. Pooled data of three years exhibited that higher grain yield, straw yield, net return, B:C ratio and nitrogen uptake were recorded under application of nitrogen in three splits as $1 / 3$ at 10 days after emergence+ $1 / 3$ at active tillering $+1 / 3$ at panicle initiation which was, however, at par with four splits of nitrogen as $1 / 4$ at 10 days after emergence $+1 / 4$ at active tillering+ $1 / 4$ at panicle initiation+ $1 / 4$ at flowering stage. Three splitting of nitrogen produced an increase of 16.92 and $1.47 \%$ in grain yield, 11.64 and $2.16 \%$ in straw yield, 26.78 and $2.90 \%$ in net return, 15.71 and $2.37 \%$ in B: C ratio, 41.08 and $6.30 \%$ in grain nitrogen uptake, 46.68 and $4.60 \%$ in straw nitrogen uptake and 42.28 and $5.86 \%$ in total nitrogen uptake as compared to two and four splits, respectively. Application of nitrogen at 10 days after emergence exhibited an increase of $7.80 \%$ in grain yield, $5.17 \%$ in straw yield, $12.37 \%$ in net return, $7.64 \%$ in $\mathrm{B}$ : $\mathrm{C}$ ratio and $13.35 \%$ in total $\mathrm{N}$ uptake as compared to basal application of nitrogen in aerobic rice.

\section{Introduction}

Rice feeds more than half the world's population. It is main staple food of India cultivated in wide variety of ecosystem and management levels. Rice is cultivated in the country in $45.5 \mathrm{~m}$ ha with productivity of 2393 kg/ha (Anonymous 2013). Chhattisgarh 
is mainly rice growing state and known as "Rice bowl" due to the highest area in the state. It is cultivated in $3.67 \mathrm{~m}$ ha area which is about $75 \%$ area of kharif season with productivity of $2041 \mathrm{~kg} / \mathrm{ha}$ (Anonymous, 2014). Rice requires large amount of water (1200 $\mathrm{mm}$ ) for production and is having low water use efficiency. With ever increasing demand of water for non-agricultural needs, water available for agriculture is likely to become scarce in future and would not be able to support those levels of production in conventional method of rice cultivation. Further, due to faulty irrigation practice and non-judicious use of water, underground water level is also declining day by day and situation is alarming in some of the location of the country. The International Rice Research Institute developed the 'aerobic rice technology' to address the water crises in tropical agriculture. In aerobic rice system, rice crop is established in non-puddled, nonflooded fields (Singh et al., 2008 and Rajakumar et al., 2009) and cultivated like an upland crop (unsaturated condition) with adequate inputs and supplementary irrigation when rainfall is insufficient. Nitrogen is the most limiting nutrient for yield of rice. Nitrogen management is essential for rice under aerobic cultivation as the nitrogen use efficiency is very low, application of appropriate quantity of nitrogen at right time is perhaps the simplest agronomic solution for improving the use efficiency of nitrogen (Devi et al., 2012). Due to aerobic environment, applied nitrogen is lost very fast and requires frequent application. Prudente et al., (2008) reported that proper amount and timing of application are responsible for reduction in $\mathrm{N}$ losses and cost of production which resulted in increased the fertilizer use efficiency and yield. There is lack of sufficient information on nitrogen management with respect to level and splitting of nitrogen in aerobic rice, a study was undertaken to find out effect of levels and scheduling of nitrogen on grain yield, economics and nitrogen uptake of rice cultivation in vertisols of Chhattisgarh plains agro climatic zone.

\section{Materials and Methods}

A field experiment was conducted at Agriculture Instructional cum Research Farm, Raipur (Chhattisgarh) during three consecutive kharif season of 2012, 2013 and 2014. The experimental soil was clay in texture, neutral in reaction (7.2), low in nitrogen $(198 \mathrm{~kg} / \mathrm{ha})$, medium in phosphorus $(24 \mathrm{~kg} / \mathrm{ha})$ and high in potassium content (230 $\mathrm{kg} / \mathrm{ha}$ ). The experiment was laid out in split plot design replicated thrice. Two levels of nitrogen in main plot viz., $120 \mathrm{~kg}$ N/ha and 150 $\mathrm{kg} \mathrm{N} / \mathrm{ha}$ and six nitrogen schedules in sub plot viz., S1-2 splits (1/2 at basal $+1 / 2$ at panicle initiation), S2- 2 splits ( $1 / 2$ at 10 days after emergence $+1 / 2$ at panicle initiation), S3- 3 splits $(1 / 3$ at basal $+1 / 3$ at active tillering $+1 / 3$ at panicle initiation), S4- 3 splits ( $1 / 3$ at 10 days after emergence $+1 / 3$ at active tillering + $1 / 3$ at panicle initiation), S5-4 splits (1/4 basal $+1 / 4$ at active tillering $+1 / 4$ at panicle initiation $+1 / 4$ at flowering), and S6-4 splits (1/4 at 10 days after emergence $+1 / 4$ at active tillering $+1 / 4$ at panicle initiation $+1 / 4$ at flowering) was assigned. The test variety was IGKV R1 coarse seed maturing in 125 days and semi dwarf in nature. The crop was sown on 25-27 June during each year in well prepared aerobic soil under moist condition. The recommended level of phosphorus $(60 \mathrm{~kg}$ $\mathrm{P}_{2} \mathrm{O}_{5} / \mathrm{ha}$ ) and potassium $\left(50 \mathrm{~kg} \mathrm{~K}_{2} \mathrm{O}\right.$ ) were applied at the time of sowing. The weeds were managed by applying pre-emergence herbicide (Pendimethalin@1.0 kg/ha) followed by post emergence herbicide (Bispyribac sodium @ $20 \mathrm{~g} / \mathrm{ha}$ at $20 \mathrm{DAS}$ ) and need based manual weeding to keep the field free of weeds. The crop was irrigated just after sowing and further irrigations were given to fulfill the demand of water and none of the stage had standing water. The yield and yield attributing 
characters were recorded from net plot area. Harvest index was calculated by dividing grain yield by total dry matter yield and multiplying by 100 . Gross and net returns were computed considering the existing market price of the inputs and output. Benefit: cost ratio (B: C ratio) was worked out for different treatments by dividing the gross returns by the corresponding cost of cultivation as described by Donald (1962). Nitrogen content in rice grain and straw were analysed using micro Kjeldhal method as described by Piper (1966) and uptake of nitrogen was calculated by multiplying $\mathrm{N}$ content and respective yield. The total uptake of nitrogen was calculated by summing grain and straw $\mathrm{N}$ uptake. The data were statistically analysed as suggested by Gomez and Gomez (1983).

\section{Results and Discussion}

\section{Yield attributes}

Application of different levels of nitrogen did not exhibit any significant effect on yield attributes (panicle numbers, panicle weight and test weight) of aerobic rice (Table 1). However, nitrogen application schedule significantly affected the yield attributes. Increasing number of splits of nitrogen increased panicle numbers $/ \mathrm{m} 2$ and test weight, however panicle weight was increased up to three splitting. Four splitting of nitrogen produced 13.24 and $4.71 \%$ higher number of panicles and 4.36 and $1.59 \%$ higher test weight as compared to two and three splits, respectively. The higher panicle weight was recorded with three splitting of nitrogen which was 14.20 and $0.64 \%$ higher as compared to two and four splits. Time of nitrogen application had also effect on number of panicles/m2, panicle weight and test weight. Application of nitrogen at 10 days after emergence exhibited increase of $4.02 \%$ in number of panicles $/ \mathrm{m} 2,6.90 \%$ in panicle weight and $1.79 \%$ in test weight compared to basal application of nitrogen.

Based on pooled data of three years, significantly the highest number of panicles was recorded with four splits of nitrogen as $1 / 4$ at 10 days after emergence $+1 / 4$ at active tillering $+1 / 4$ at panicle initiation $+1 / 4$ at flowering stage, which was however at par with another scheduling of four splits i.e. 1/4 basal $+1 / 4$ active tillering $+1 / 4$ at panicle initiation $+1 / 4$ at flowering stage for panicle number and with three splits (1/3 at 10 days after emergence $+1 / 3$ at active tillering $+1 / 3$ at panicle initiation) for test weight also. Panicle weight was significantly more under three splits as $1 / 3$ at 10 days after emergence + $1 / 3$ at active tillering $+1 / 3$ at panicle initiation, however, it was at par with three splits $(1 / 3$ at basal $+1 / 3$ at active tillering $+1 / 3$ at panicle initiation) and four splits (1/4 basal $+1 / 4$ active tillering $+1 / 4$ at panicle initiation $+1 / 4$ at flowering stage and $1 / 4$ at 10 days after emergence $+1 / 4$ at active tillering $+1 / 4$ at panicle initiation $+1 / 4$ at flowering stage). Significantly, the lowest values of yield attributes (panicle number, panicle weight and test weight) were recorded under application of nitrogen in two splits as $1 / 2$ at basal $+1 / 2$ at panicle initiation stage which was, however, at par with nitrogen application in two splits as $1 / 2$ at 10 days after emergence $+1 / 2$ at panicle initiation stage. More supply of carbohydrates from post anthesis photosynthesis might have increased the grain filling rate consequently increased panicle weight and test weight. Similar of the results was also reported by Lin (2005), Mahajan et al., (2011) and Zhang et al., (2007).

\section{Grain yield, straw yield and harvest index}

Application of different levels of nitrogen did not record any significant effect on grain yield, straw yield and harvest index of aerobic 
rice (Table 2). However, nitrogen application schedule significantly affected theses parameters. Increasing number of splits of nitrogen increased grain yield, straw yield and harvest index upto three splits, thereafter no increase in these parameters was observed. Three splitting of nitrogen produced 16.92 and $1.47 \%$ higher grain yield and 11.64 and $2.16 \%$ higher straw yield as compared to two and four splits, respectively. Time of nitrogen application had also effect on number of panicles $/ \mathrm{m} 2$, panicle weight and test weight. Application of nitrogen at 10 days after emergence exhibited increase of $7.80 \%$ in grain yield, $5.17 \%$ in straw yield and $1.84 \%$ in harvest index as compared to basal application of nitrogen.

Pooled data of three years indicated that significantly higher grain yield and straw yield were recorded under application of nitrogen in three splits as $1 / 3$ at 10 days after emergence + $1 / 3$ at active tillering $+1 / 3$ at panicle initiation which was, however, at par with four splits of nitrogen as $1 / 4$ at 10 days after emergence $+1 / 4$ at active tillering $+1 / 4$ at panicle initiation $+1 / 4$ at flowering stage. The higher harvest index was recorded under three splits as $1 / 3$ at 10 days after emergence $+1 / 3$ at active tillering $+1 / 3$ at panicle initiation and four splits as $1 / 4$ at 10 days after emergence $+1 / 4$ at active tillering $+1 / 4$ at panicle initiation $+1 / 4$ at flowering stage which was however at par with another four splits (1/4 at 10 days after emergence $+1 / 4$ at active tillering $+1 / 4$ at panicle initiation $+1 / 4$ at flowering stage) and three splits $(1 / 3$ at 10 days after emergence + $1 / 3$ at active tillering $+1 / 3$ at panicle initiation) of nitrogen application.

The lowest grain yield, straw yield and harvest were recorded under application of nitrogen in two splits as $1 / 2$ at basal $+1 / 2$ at panicle initiation stage with significant difference to others. Increase in leaf area increased the area for interception and absorption of specific wavelength of light necessary for photosynthesis and also more chlorophyll content resulted in higher dry matter accumulation thereby increased the absorption of nitrogen subsequently increased the grain yield and straw yield. Similar findings were also reported by Singh and Thakur (2007) and Algeson and Rajababu (2011).

Table.1 Yield attributes of aerobic rice as influenced by nitrogen levels and scheduling

\begin{tabular}{|c|c|c|c|c|c|c|c|c|c|c|c|c|}
\hline \multirow[t]{2}{*}{ Treatments } & \multicolumn{4}{|c|}{ Panicles/m2, No. } & \multicolumn{4}{|c|}{ Panicle weight, g } & \multicolumn{4}{|c|}{ Test weight, $\mathrm{g}$} \\
\hline & 2012 & 2013 & 2014 & $\begin{array}{c}\text { Pooled } \\
\text { mean }\end{array}$ & 2012 & 2013 & 2014 & $\begin{array}{c}\text { Pooled } \\
\text { mean }\end{array}$ & 2012 & 2013 & 2014 & $\begin{array}{c}\text { Pooled } \\
\text { mean }\end{array}$ \\
\hline \multicolumn{13}{|c|}{ Nitrogen levels (kg/ha) } \\
\hline N1-120 kg/ha & 264 & 257 & 255 & 259 & 4.08 & 4.09 & 2.94 & 3.70 & 28.4 & 24.2 & 31.5 & 28.0 \\
\hline N2-150 kg/ha & 270 & 268 & 262 & 267 & 4.17 & 4.26 & 3.09 & 3.84 & 28.7 & 24.5 & 31.7 & 28.3 \\
\hline $\mathrm{CD}(\mathrm{P}=0.05)$ & NS & NS & NS & NS & NS & NS & NS & NS & NS & NS & NS & NS \\
\hline \multicolumn{13}{|c|}{ Scheduling of nitrogen } \\
\hline S-1 (1/2 B+1/2 PI) & 255 & 226 & 229 & 237 & 3.70 & 3.56 & 2.70 & 3.32 & 27.6 & 23.5 & 30.9 & 27.3 \\
\hline $\begin{array}{l}\text { S-2 (1/2 } 10 \text { DAE+ } \\
1 / 2 \mathrm{PI})\end{array}$ & 260 & 253 & 250 & 254 & 4.19 & 3.75 & 2.81 & 3.58 & 27.9 & 23.8 & 31.5 & 27.7 \\
\hline $\begin{array}{l}\mathrm{S}-3(1 / 3 \mathrm{~B}+1 / 3 \mathrm{AT}+ \\
1 / 3 \mathrm{PI})\end{array}$ & 266 & 262 & 256 & 261 & 4.05 & 4.26 & 3.10 & 3.80 & 28.4 & 24.0 & 31.2 & 27.9 \\
\hline $\begin{array}{l}\text { S-4 (1/3 10 DAE+ } \\
1 / 3 \mathrm{AT}+1 / 3 \mathrm{PI})\end{array}$ & 271 & 272 & 267 & 270 & 4.24 & 4.74 & 3.27 & 4.08 & 29.4 & 25.0 & 31.4 & 28.6 \\
\hline $\begin{array}{l}\text { S-5 }(1 / 4 \mathrm{~B}+1 / 4 \mathrm{AT}+ \\
1 / 4 \mathrm{PI}+1 / 4 \mathrm{~F})\end{array}$ & 275 & 279 & 274 & 276 & 4.24 & 4.20 & 3.00 & 3.81 & 28.8 & 24.5 & 32.1 & 28.5 \\
\hline $\begin{array}{l}\text { S-6 (1/4 10 DAE + } \\
1 / 4 \mathrm{AT}+1 / 4 \mathrm{PI}+1 / 4 \mathrm{~F})\end{array}$ & 277 & 285 & 277 & 280 & 4.30 & 4.52 & 3.24 & 4.02 & 29.2 & 25.2 & 32.4 & 28.9 \\
\hline $\mathrm{CD}(\mathrm{P}=0.05)$ & 15 & 18 & 30 & 19 & 0.26 & 0.39 & 0.24 & 0.32 & 0.5 & 0.7 & NS & 0.9 \\
\hline
\end{tabular}


Table.2 Grain yield, straw yield and harvest index of aerobic rice as influenced by nitrogen levels and scheduling

\begin{tabular}{|c|c|c|c|c|c|c|c|c|c|c|c|c|}
\hline \multirow[t]{2}{*}{ Treatments } & \multicolumn{4}{|c|}{ Grain yield, kg/ha } & \multicolumn{4}{|c|}{ Straw yield, kg/ha } & \multicolumn{4}{|c|}{ Harvest index, \% } \\
\hline & 2012 & 2013 & 2014 & $\begin{array}{c}\text { Pooled } \\
\text { mean }\end{array}$ & 2012 & 2013 & 2014 & $\begin{array}{c}\text { Pooled } \\
\text { mean }\end{array}$ & 2012 & 2013 & 2014 & $\begin{array}{c}\text { Pooled } \\
\text { mean }\end{array}$ \\
\hline \multicolumn{13}{|c|}{ Nitrogen levels (kg/ha) } \\
\hline $\mathrm{N} 1-120 \mathrm{~kg} / \mathrm{ha}$ & 5342 & 4018 & 3739 & 4366 & 6771 & 7200 & 5710 & 6560 & 44.1 & 35.8 & 39.6 & 39.8 \\
\hline N2-150 kg/ha & 5543 & 4336 & 3917 & 4599 & 6848 & 7322 & 5780 & 6650 & 44.7 & 36.9 & 40.4 & 40.7 \\
\hline $\mathrm{CD}(\mathrm{P}=0.05)$ & NS & 232 & NS & NS & NS & 79 & NS & NS & NS & 0.5 & NS & NS \\
\hline \multicolumn{13}{|c|}{ Scheduling of nitrogen } \\
\hline $\mathrm{S}-1(1 / 2 \mathrm{~B}+1 / 2 \mathrm{PI})$ & 5067 & 3060 & 3418 & 3848 & 6630 & 5713 & 5471 & 5938 & 43.3 & 34.9 & 38.5 & 38.9 \\
\hline $\begin{array}{l}\text { S-2 (1/2 } 10 \text { DAE+ } \\
1 / 2 \mathrm{PI})\end{array}$ & 5297 & 3710 & 3741 & 4249 & 6766 & 6750 & 5721 & 6412 & 43.9 & 35.5 & 39.5 & 39.6 \\
\hline $\begin{array}{l}\text { S-3 (1/3 B+1/3 AT } \\
+1 / 3 \mathrm{PI})\end{array}$ & 5376 & 4397 & 3890 & 4554 & 6791 & 7594 & 5803 & 6729 & 44.2 & 36.7 & 40.1 & 40.3 \\
\hline $\begin{array}{l}\text { S-4 (1/3 10 DAE + } \\
1 / 3 \mathrm{AT}+1 / 3 \mathrm{PI})\end{array}$ & 5558 & 5025 & 4155 & 4913 & 6861 & 8389 & 5923 & 7058 & 44.8 & 37.5 & 41.2 & 41.1 \\
\hline $\begin{array}{l}\mathrm{S}-5(1 / 4 \mathrm{~B}+1 / 4 \mathrm{AT} \\
+1 / 4 \mathrm{PI}+1 / 4 \mathrm{~F})\end{array}$ & 5638 & 4222 & 3786 & 4549 & 6894 & 7361 & 5726 & 6660 & 45.0 & 36.5 & 39.8 & 40.4 \\
\hline $\begin{array}{l}\text { S-6 }(1 / 410 \mathrm{DAE} \\
+1 / 4 \mathrm{AT}+1 / 4 \\
\mathrm{PI}+1 / 4 \mathrm{~F})\end{array}$ & 5719 & 4647 & 3977 & 4781 & 6921 & 7762 & 5823 & 6835 & 45.2 & 37.5 & 40.6 & 41.1 \\
\hline $\mathrm{CD}(\mathrm{P}=0.05)$ & 330 & 181 & 340 & 288 & 180 & 137 & 189 & 234 & 1.0 & 0.9 & 1.1 & 1.2 \\
\hline
\end{tabular}

Table.3 Economics of aerobic rice as influenced by nitrogen levels and scheduling

\begin{tabular}{|c|c|c|c|c|c|c|c|c|c|c|c|c|}
\hline \multirow[t]{2}{*}{ Treatments } & \multicolumn{4}{|c|}{ Gross return, Rs/ha } & \multicolumn{4}{|c|}{ Net return, Rs/ha } & \multicolumn{4}{|c|}{ B:C ratio } \\
\hline & 2012 & 2013 & 2014 & $\begin{array}{l}\text { Pooled } \\
\text { mean }\end{array}$ & 2012 & 2013 & 2014 & $\begin{array}{l}\text { Pooled } \\
\text { mean }\end{array}$ & 2012 & 2013 & 2014 & $\begin{array}{l}\text { Pooled } \\
\text { mean }\end{array}$ \\
\hline \multicolumn{13}{|c|}{ Nitrogen levels (kg/ha) } \\
\hline $\mathrm{N} 1-120 \mathrm{~kg} / \mathrm{ha}$ & 70161 & 56236 & 53705 & 60034 & 49820 & 34819 & 31028 & 38556 & 3.45 & 2.63 & 2.37 & 2.81 \\
\hline N2-150 kg/ha & 72712 & 60463 & 56161 & 63112 & 52002 & 38677 & 33115 & 41264 & 3.51 & 2.78 & 2.44 & 2.91 \\
\hline $\mathrm{CD}(\mathrm{P}=0.05)$ & NS & 2452 & NS & NS & NS & 831 & NS & NS & NS & 0.12 & NS & NS \\
\hline \multicolumn{13}{|c|}{ Scheduling of nitrogen } \\
\hline $\begin{array}{l}S-1(1 / 2 \\
B+1 / 2 \text { PI })\end{array}$ & 66652 & 42942 & 49221 & 52938 & 46303 & 21524 & 26556 & 31461 & 3.28 & 2.00 & 2.17 & 2.48 \\
\hline $\begin{array}{l}\text { S-2 (1/2 10 } \\
\text { DAE+ 1/2PI) }\end{array}$ & 69596 & 51976 & 53738 & 58437 & 49246 & 30558 & 31073 & 36959 & 3.42 & 2.43 & 2.37 & 2.74 \\
\hline $\begin{array}{l}\text { S-3(1/3 B+ } \\
\text { 1/3AT+1/3PI) }\end{array}$ & 70596 & 61398 & 55806 & 62600 & 50070 & 39797 & 32944 & 40937 & 3.44 & 2.84 & 2.44 & 2.91 \\
\hline $\begin{array}{l}\mathrm{S}-4(1 / 310 \\
\mathrm{DAE}+1 / 3 \\
\mathrm{AT}+1 / 3 \mathrm{PI})\end{array}$ & 72906 & 70022 & 59469 & 67466 & 52380 & 48421 & 36607 & 45803 & 3.55 & 3.24 & 2.60 & 3.13 \\
\hline $\begin{array}{l}\mathrm{S}-5(1 / 4 \mathrm{~B}+ \\
1 / 4 \mathrm{AT}+1 / 4 \\
\mathrm{PI}+1 / 4 \mathrm{~F})\end{array}$ & 73922 & 58989 & 54353 & 62421 & 53221 & 37205 & 31294 & 40573 & 3.57 & 2.71 & 2.36 & 2.88 \\
\hline $\begin{array}{l}\text { S-6 }(1 / 410 \\
\text { DAE +1/4AT } \\
+1 / 4 \mathrm{PI}+1 / 4 \mathrm{~F})\end{array}$ & 74948 & 64756 & 56999 & 65568 & 54247 & 42972 & 33940 & 43720 & 3.62 & 2.97 & 2.47 & 3.02 \\
\hline $\mathrm{CD}(\mathrm{P}=0.05)$ & 3312 & 1943 & 3456 & 3541 & 3312 & 1943 & 3456 & 3541 & 0.23 & 0.18 & 0.21 & 0.24 \\
\hline
\end{tabular}


Table.4 Effect of $\mathrm{N}$ levels and scheduling on nitrogen uptake of aerobic rice

\begin{tabular}{|c|c|c|c|c|c|c|c|c|c|c|c|c|}
\hline \multirow[t]{2}{*}{ Treatments } & \multicolumn{4}{|c|}{ Grain N uptake, kg/ha } & \multicolumn{4}{|c|}{ Straw N uptake, kg/ha } & \multicolumn{4}{|c|}{ Total N uptake, kg/ha } \\
\hline & 2012 & 2013 & 2014 & $\begin{array}{c}\text { Pooled } \\
\text { mean }\end{array}$ & 2012 & 2013 & 2014 & $\begin{array}{c}\text { Pooled } \\
\text { mean }\end{array}$ & 2012 & 2013 & 2014 & $\begin{array}{c}\text { Pooled } \\
\text { mean }\end{array}$ \\
\hline \multicolumn{13}{|c|}{ Nitrogen levels (kg/ha) } \\
\hline $\mathrm{N} 1-120 \mathrm{~kg} / \mathrm{ha}$ & 57.05 & 41.87 & 39.33 & 46.09 & 16.79 & 17.56 & 14.22 & 16.19 & 73.84 & 59.43 & 53.55 & 62.28 \\
\hline N2-150 kg/ha & 63.86 & 46.77 & 42.26 & 50.96 & 17.53 & 19.12 & 14.91 & 17.19 & 81.39 & 65.89 & 57.18 & 68.15 \\
\hline $\mathrm{CD}(\mathrm{P}=0.05)$ & 3.16 & 2.28 & 2.41 & 3.28 & NS & 0.95 & NS & NS & 4.14 & 2.70 & 3.12 & 4.53 \\
\hline \multicolumn{13}{|c|}{ Scheduling of nitrogen } \\
\hline $\mathrm{S}-1(1 / 2 \mathrm{~B}+1 / 2 \mathrm{PI})$ & 50.26 & 26.31 & 32.92 & 36.50 & 14.19 & 10.67 & 11.00 & 11.95 & 64.45 & 36.98 & 43.91 & 48.45 \\
\hline $\begin{array}{l}\text { S-2 (1/2 10 DAE } \\
+1 / 2 \mathrm{PI})\end{array}$ & 53.61 & 33.18 & 37.34 & 41.37 & 15.22 & 14.27 & 12.36 & 13.95 & 68.83 & 47.45 & 49.69 & 55.32 \\
\hline $\begin{array}{l}\mathrm{S}-3(1 / 3 \mathrm{~B}+1 / 3 \\
\mathrm{AT}+1 / 3 \mathrm{PI})\end{array}$ & 60.43 & 47.38 & 43.57 & 50.46 & 17.38 & 20.12 & 16.13 & 17.88 & 77.81 & 67.50 & 59.70 & 68.34 \\
\hline $\begin{array}{l}\text { S-4 (1/3 10 DAE } \\
+1 / 3 \mathrm{AT}+1 / 3 \mathrm{PI}) \\
\end{array}$ & 63.67 & 62.35 & 52.19 & 59.40 & 18.04 & 24.74 & 17.53 & 20.11 & 81.72 & 87.09 & 69.72 & 79.51 \\
\hline $\begin{array}{l}\mathrm{S}-5(1 / 4 \mathrm{~B}+1 / 4 \\
\mathrm{AT}+1 / 4 \mathrm{PI}+1 / 4 \mathrm{~F}) \\
\end{array}$ & 66.70 & 42.10 & 39.56 & 49.45 & 18.82 & 18.38 & 14.43 & 17.21 & 85.52 & 60.48 & 53.99 & 66.66 \\
\hline $\begin{array}{l}\text { S-6 (1/4 10 DAE } \\
1 / 4 A T+1 / 4 \text { PI+ } \\
1 / 4 F)\end{array}$ & 68.86 & 52.60 & 40.25 & 53.90 & 19.24 & 21.85 & 16.25 & 19.11 & 88.10 & 74.45 & 56.49 & 73.01 \\
\hline $\mathrm{CD}(\mathrm{P}=0.05)$ & 5.62 & 3.96 & 4.31 & 6.25 & 2.48 & 1.65 & 2.12 & 2.10 & 6.27 & 4.69 & 5.25 & 7.32 \\
\hline
\end{tabular}

\section{Economics}

Application of different levels of nitrogen did not influence significantly gross return, net return and B: C ratio of aerobic rice (Table 3). However, nitrogen application schedule significantly affected theses parameters. Increasing number of splits of nitrogen increased gross return, net return and B: C ratio upto three splits, thereafter no increase in these parameters was observed. Three splitting of nitrogen produced 16.78 and $1.62 \%$ higher gross return, 26.78 and $2.90 \%$ higher net return and 15.71 and $2.37 \%$ higher $\mathrm{B}: \mathrm{C}$ ratio as compared to two and four splits, respectively. Time of nitrogen application had also effect on gross return, net return and B: C ratio. Application of nitrogen at 10 days after emergence exhibited increase of $7.73 \%$ in gross return, $12.37 \%$ in net return and $7.64 \%$ in $\mathrm{B}: \mathrm{C}$ ratio as compared to basal application of nitrogen.

Pooled data of three years exhibited that significantly the highest gross return, net return and $\mathrm{B}$ : $\mathrm{C}$ ratio were recorded under application of nitrogen in three splits as $1 / 3$ at 10 days after emergence $+1 / 3$ at active tillering $+1 / 3$ at panicle initiation which was, however, at par with four splits of nitrogen as $1 / 4$ at 10 days after emergence $+1 / 4$ at active tillering $+1 / 4$ at panicle initiation $+1 / 4$ at flowering stage. Significantly, the lowest gross return, net return and $\mathrm{B}$ : $\mathrm{C}$ ratio were recorded under application of nitrogen in two splits as $1 / 2$ at basal $+1 / 2$ at panicle initiation stage. Gross return is the result of higher grain and straw yield under the respective treatment.

\section{Nitrogen uptake}

Application of different levels of nitrogen significantly influenced the grain $\mathrm{N}$ uptake and total $\mathrm{N}$ uptake, however straw $\mathrm{N}$ uptake was not affected (Table 4). Nitrogen application schedule significantly affected grain nitrogen uptake, straw nitrogen uptake as well as total nitrogen uptake. Application of $150 \mathrm{~kg}$ nitrogen/ha showed significantly higher grain $\mathrm{N}$ uptake and total $\mathrm{N}$ uptake by aerobic rice as compared to application of 120 
$\mathrm{kg}$ nitrogen/ha. Increase in grain nitrogen uptake was $10.57 \%$ and total uptake of nitrogen was $9.42 \%$ with the application of $150 \mathrm{kgN} / \mathrm{ha}$ as compared to $120 \mathrm{kgN} / \mathrm{ha}$. More nitrogen uptake under higher level of nitrogen applied may be owing to higher grain and straw yield resulting in increased uptake. These findings are in accordance with Kumar and Rao (1992).Increasing number of splits of nitrogen increased grain nitrogen uptake, straw nitrogen uptake and total nitrogen uptake upto three splits, thereafter no increase in these parameters was observed. Three splitting of nitrogen produced 41.08 and $6.30 \%$ higher grain nitrogen uptake, 46.68 and $4.60 \%$ higher straw nitrogen uptake and 42.28 and $5.86 \%$ higher total nitrogen uptake as compared to two and four splits, respectively. Time of nitrogen application had also effect on grain nitrogen uptake, straw nitrogen uptake and total nitrogen uptake. Application of nitrogen at 10 days after emergence exhibited increase of $13.35 \%$ in grain $\mathrm{N}$ uptake, $13.42 \%$ in straw $\mathrm{N}$ uptake and $13.35 \%$ in total $\mathrm{N}$ uptake as compared to basal application of nitrogen.

Based on pooled data of three years, significantly the highest grain nitrogen uptake, straw nitrogen uptake and total nitrogen uptake were recorded under application of nitrogen in three splits as $1 / 3$ at 10 days after emergence $+1 / 3$ at active tillering $+1 / 3$ panicle initiation which was, however, at par with four splits of nitrogen as $1 / 4$ at 10 days after emergence $+1 / 4$ at active tillering $+1 / 4$ at panicle initiation $+1 / 4$ at flowering stage. Significantly, the lowest N uptake grain nitrogen uptake, straw nitrogen uptake and total nitrogen uptake were recorded under application of nitrogen in two splits as $1 / 2$ at basal $+1 / 2$ at panicle initiation stage which was however at par with nitrogen application in two splits as $1 / 2$ at 10 days after emergence $+1 / 2$ at panicle initiation stage. Application of nitrogen in splits according to crop requirement might have reduced the loss of nitrogen and increased the nitrogen absorption consequently better utilization of applied nitrogen leads to higher dry matter accumulation and finally resulted in higher nitrogen uptake. These findings are conformity the earlier findings of Zaidi et al., (2007).

\section{References}

Algesan and Raja Babu, 2011. Impact of different nitrogen levels and time of application on grain yield and yield attributes of wet seeded rice. International Journals for Food, Agriculture and Vetenary Science. 1(1): $1-5$.

Anonymous, 2013. Annual Report. Department of Agriculture and Cooperation, Ministry of Agriculture, Government of India, New Delhi. pp. 4.

Anonymous, 2014. Krishi Digdarshika. Directorate of Extension Services. IGKV, Raipur, Chhattisgarh. pp. 4.

Devi, M.G., Reddy, S.T., Sumathi V., Reddy, S. and Aruna, A. 2012. Influence of level and time of $\mathrm{N}$ application on yield, nutrient uptake and post-harvest nitrogen status of soil in aerobic rice. Current Botanica. 6(1): 98-102.

Donald, 1962. In search of yield. J. Australian Agril. Sci. 28: 171-178.

Gomez, K.A., Gomez, A.A., 1983. Statistical procedures for agricultural research. An International Rice Research Institute book, John Wiley and Sons, New York, 204.

Kumar, K. and Rao, K. V. P. 1992. Nitrogen and phosphorus requirement of upland rice in Manipur. Oryza. 29: 306-309.

Lin, S., Sattelmacher and Bruch, H. 2005. Lowland and aerobic rice respond differently to ammonium and nitrate supply during early growth stages. Journal of Plant Nutrition. 28:1495- 
1510.

Mahajan, G., Chauhan, B.S. and Gill, M.S. 2011. Optimal nitrogen fertilization timing and rate in dry direct seeded rice in north- west India. Agronomy Journal. 103(6): 1676-1682.

Piper, C.S. 1966. Soil and plant analysis. Indian Edn. Hans. Publ., Bombay. pp. 19136

Prudente, J.A., Sigua, G.C., Kangchum, M. and Prudente, A.D. 2008. Improving yield and nutrient uptake potentials of Japonica and Indica rice varieties. World Journal of Agriculture Science. 4(4): 427- 434.

Rajkumar, B., Subramanian, E., Ramesh, T., Maragatham, N., Martin, G.J. and Thiyagarajan, G. 2009. Striding towards aerobic rice cultivation - a review. Agriculture Reviews. 30(3): 213-218.
Singh, H. and Thakur, R.B. 2007. Effect of level and scheduling of nitrogen application on yield and quality of Basmati rice. Journal of Applied Bioscience 33(2):118-121

Singh, S., Ladha, J.K., Gupta, R.K., Bhushan, L. and Rao A.N. 2008. Weed management in aerobic rice systems under varying establishment methods. Crop Protection. 27: 660-667.

Zaidi, Tripathi, H.P. and Singh, B. 2007. Effect of nitrogen application timings on $\mathrm{N}$ use efficiency in rice. Oryza. 36(4): 322-326.

Zhang, Y.H., Fan, J.B., Zhang, Y.L., Haung, Q.W. and Shen, Q.R. 2007. N accumulation and translocation in four japonica rice cultivars at different $\mathrm{N}$ rates. Pedosphere. 17: 792-800.

\section{How to cite this article:}

Sonboir H. L., N. Pandey, Bhujendra Kumar and Sahu B. K. 2020. Effect of Nitrogen Levels and Scheduling on Yield and Economics of Aerobic Rice (Oryza sativa L.) in vertisols of Chhattisgarh Plains. Int.J.Curr.Microbiol.App.Sci. 9(03): 3186-3194. doi: https://doi.org/10.20546/ijcmas.2020.903.365 